\title{
Methods for microbial DNA extraction from soil for PCR amplification
}

\author{
C.Yeates*, M.R.Gillings, A.D.Davison, N.Altavilla, D.A.Veal
}

Key Centre for Biodiversity and Bioresources, School of Biological Sciences, Macquarie University, Sydney, NSW 2109, Australia. *To whom correspondence should be addressed. E-mail: cyeates@rna.bio.mq.edu.au

\begin{abstract}
Amplification of DNA from soil is often inhibited by co-purified contaminants. A rapid, inexpensive, large-scale DNA extraction method involving minimal purification has been developed that is applicable to various soil types (1). DNA is also suitable for PCR amplification using various DNA targets. DNA was extracted from $100 \mathrm{~g}$ of soil using direct lysis with glass beads and SDS followed by potassium acetate precipitation, polyethylene glycol precipitation, phenol extraction and isopropanol precipitation. This method was compared to other DNA extraction methods with regard to DNA purity and size.
\end{abstract}

\section{INTRODUCTION}

The inability to culture most microorganisms from environmental samples is a fundamental obstacle to understanding microbial ecology and diversity (2). The use of DNA-based techniques can overcome this limitation by allowing the fate of particular genes or organisms to be monitored directly in environmental samples. Techniques to extract DNA from soil and sediment initially used large samples of $100 \mathrm{~g}(3,4)$. These extracts were usually contaminated with humic acids which interfered with subsequent molecular biological manipulations. Extensive purification steps were then required to successfully amplify a PCR product, including CsCl-ethidium bromide density gradient centrifugation (4-6), or the use of commercial reagents (7-11). These steps increase both the complexity and the cost of the technique. This paper describes in detail a method for extracting DNA from soil which involves minimal purification prior to PCR amplification (1). The method is compared to other commonly used DNA extraction methods. A PCR product was obtained rapidly and inexpensively from large amounts of soil, even when contaminated with heavy metals.

\section{MATERIALS AND METHODS}

\section{Soils}

Soil (loamy sand) was collected on campus at Macquarie University to compare various DNA extraction methods. Soil samples were also collected from Western Sydney, Macquarie University, Ku-Ring-Gai Chase National Park and Balmain Power Station in central Sydney, to validate the bead beating

(C)1998 Biological Procedures Online. All rights reserved. Paper-based copying permitted for internal use for educational or non-profit purposes only. Otherwise, this article may be copied to paper provided that \$US15 per copy is paid directly to Biological Procedures Online, GMO 106 Box 44, Waterloo ON, Canada N2L 3G1. Electronic copying, storage or redistribution prohibited. ISSN: 1480-9222 
technique (1) using a variety of soils. The Ku-Ring-Gai Chase National Park and the Balmain Power Station samples represent the extremes of pristine vs polluted soils and were compared by further soil testing (Biological and Chemical Research Institute, Sydney) (Table 1).

\section{DNA extraction methods investigated}

DNA extraction using bead beating (1). Extraction buffer (100 $\mathrm{ml}$ of $100 \mathrm{mM}$ Tris-HCl [pH 8.0], 100 $\mathrm{mM}$ sodium EDTA [pH 8.0], $1.5 \mathrm{M} \mathrm{NaCl}$ ) was mixed with $100 \mathrm{~g}$ (wet weight) of soil. Glass beads (100g, Bio-Spec Products, Bartesville,U.S.) were added and the sample blended in a Bead-Beater (BioSpec Products) for 2 minutes. Sodium dodecyl sulphate (SDS) was added $(10 \mathrm{ml} ; 20 \%)$ and blending continued for a further $5 \mathrm{sec}$. The sample was incubated at $65^{\circ} \mathrm{C}$ for $1 \mathrm{hr}$, transferred to centrifuge bottles $(250 \mathrm{ml})$ and centrifuged at $6000 \mathrm{~g}$ for $10 \mathrm{~min}$. The supernatant was collected, and the soil pellet re-extracted with further extraction buffer $(100 \mathrm{ml})$, incubation at $65^{\circ} \mathrm{C}$ for 10 minutes and centrifugation as above. Supernatants were transferred to centrifuge tubes (50 ml) containing a half-volume of polyethylene glycol (30\%)/sodium chloride $(1.6 \mathrm{M})$, and incubated at room temperature for $2 \mathrm{hr}$. Samples were centrifuged $(10,000 \mathrm{~g}$ for $20 \mathrm{~min}$ ) and the partially purified nucleic acid pellet resuspended in $20 \mathrm{ml}$ of TE (10 mM Tris$\mathrm{HCl}, 1 \mathrm{mM}$ sodium EDTA, pH 8.0). Potassium acetate $(7.5 \mathrm{M})$ was added to a final concentration of 0.5 M. Samples were transferred to ice for $5 \mathrm{~min}$ then centrifuged $(16,000 \mathrm{~g}, 30 \mathrm{~min})$ at $4^{\circ} \mathrm{C}$ to

Table 1: Analysis of soil samples

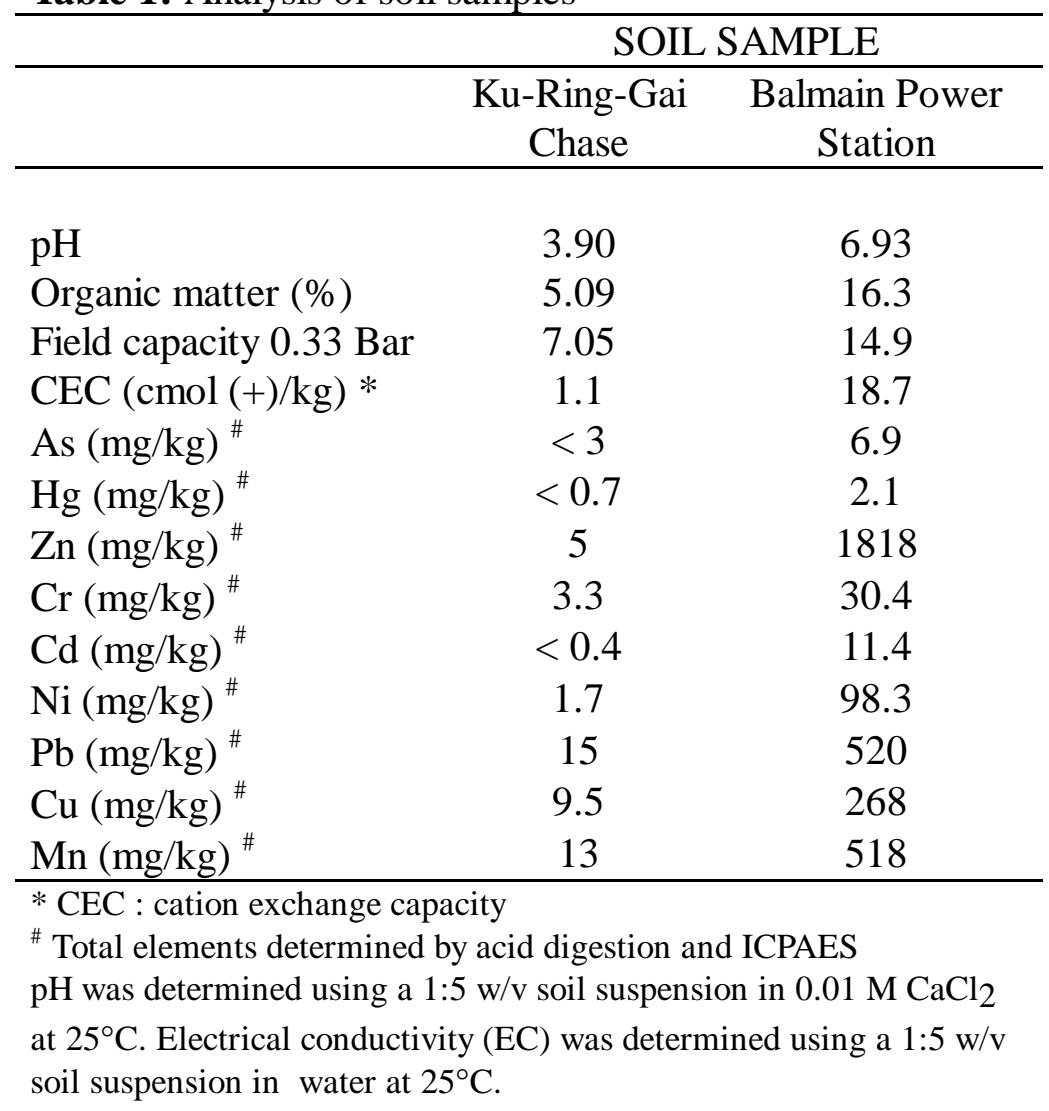
precipitate proteins and polysaccharides. The aqueous phase was extracted with phenol/chloroform and chloroform/isoamyl alcohol (12) and DNA was precipitated by adding 0.6 volume isopropanol. After 2 hrs at room temperature, DNA was pelleted by centrifugation $(16,000 \mathrm{~g}$ for $30 \mathrm{~min})$ and resuspended in TE (1 ml).

DNA extraction using sonication (modified from 13). Extraction buffer (100 ml) was mixed with soil $(50 \mathrm{~g})$ on ice. The mixture was sonicated using a High Intensity Ultrasonic Processor (Vibra Cell) with a standard $13 \mathrm{~mm}$ horn solid probe for 150 seconds. The sample was cooled in ice and the sonication repeated. SDS was added $(10 \mathrm{ml} ; 20 \%)$ and the sample incubated at $65^{\circ} \mathrm{C}$ for $1 \mathrm{hr}$. The sample was transferred to centrifuge bottles $(250 \mathrm{ml})$ and centrifuged at $6000 \mathrm{~g}$ for $10 \mathrm{~min}$. The supernatant was 
collected, and the soil pellet re-extracted with further extraction buffer $(50 \mathrm{ml})$, incubation at $65^{\circ} \mathrm{C}$ for 10 minutes and centrifuged as above. Extraction was then continued as per bead beating method.

DNA extraction using enzymatic lysis (modified from 11). Extraction buffer (100 ml) containing proteinase K $(5 \mathrm{mg})$ was mixed with soil $(50 \mathrm{~g})$ in $250 \mathrm{ml}$ centrifuge tubes. The sample was incubated at $37^{\circ} \mathrm{C}$ for 30 minutes with shaking at $180 \mathrm{rpm}$. SDS was added $(10 \mathrm{ml} ; 20 \%)$ and the sample incubated at $65^{\circ} \mathrm{C}$ for $90 \mathrm{~min}$. The supernatant was collected after centrifugation at $6000 \mathrm{~g}$ for $10 \mathrm{~min}$ at room temperature. Extraction was continued as per bead beating method.

DNA extraction from bacterial cells isolated from soil (modified from 4 and 14). The bacterial fraction of soil was separated from the inorganic or humic layer by a differential centrifugation technique (14). Bacterial cells were lysed using lysozyme and the DNA purified using ammonium acetate precipitation and ethanol precipitation (14). DNA was resuspended in TE.

\section{Test for Co-Extraction of Contaminants}

Co-extracted humic acids are the major contaminant when DNA is extracted from soil. These compounds absorb at $230 \mathrm{~nm}$ whereas DNA absorbs at $260 \mathrm{~nm}$ and protein at $280 \mathrm{~nm}$. To evaluate the purity of the extracted DNA, absorbance ratios at $260 \mathrm{~nm} / 230 \mathrm{~nm}$ (DNA / humic acids) and $260 \mathrm{~nm} / 280$ nm (DNA / protein) were determined (see Table 2 and 3).

\section{Polymerase Chain Reaction (PCR)}

DNA (1 $\mu$ l of 1:50 dilution) was mixed with $9 \mu$ l of Genereleaser ${ }^{\mathrm{TM}}$ (Bioventures Inc., Murfreesboro, Tennessee, USA) in a $0.5 \mathrm{ml}$ tube and overlaid with 2 drops of sterile mineral oil. Genereleaser ${ }^{\mathrm{TM}}$ is a proprietary agent that sequesters inhibitors of PCR. Negative controls containing water only, and Genereleaser ${ }^{\mathrm{TM}}$ only, were included in each set of reactions. Reaction tubes were heated on the high setting of a 650 Watt microwave oven for $7 \mathrm{~min}(4550 \mathrm{~W} / \mathrm{min})$ in a microwave transparent rack (Bioventures Inc.). An Erlenmeyer flask containing $100 \mathrm{ml}$ of water was included as a microwave sink. Tubes were incubated for at least $10 \mathrm{~min}$ at $80^{\circ} \mathrm{C}$ in an Omn-E PCR machine (Hybaid). PCR master mix $(40 \mu \mathrm{l})$ was then added to each tube. Final concentrations of reagents were as follows: $20 \mathrm{mM}$ $\left(\mathrm{NH}_{4}\right)_{2} \mathrm{SO}_{4}, 75 \mathrm{mM}$ Tris-HCl (pH 9.0), 0.01\% (w/v) Tween 20, $2 \mathrm{mM} \mathrm{MgCl} 2,0.5 \mathrm{mM}$ of each primer, $0.2 \mathrm{mM}$ of each deoxyribonucleotide triphosphate, and $1 \mathrm{U}$ Red Hot DNA Polymerase (Advanced Biotechnologies, Surrey, UK). The following thermal cycle was performed : $94^{\circ} \mathrm{C} 3$ min $\left(1\right.$ cycle), $94^{\circ} \mathrm{C}$ $1 \mathrm{~min}, 55^{\circ} \mathrm{C} 1 \mathrm{~min}, 72^{\circ} \mathrm{C} 2 \min (35$ cycles $), 72^{\circ} \mathrm{C} 5 \min (1$ cycle $)$.

\section{Gel Electrophoresis}

An aliquot $(7 \mu \mathrm{l})$ of each amplification reaction was analysed on $2 \% \mathrm{w} / \mathrm{v}$ agarose gels cast and run in TBE buffer ( $\mathrm{pH}$ 8.3) (12). Gels were stained with ethidium bromide and photographed using transmitted U.V. light and Polaroid film (12). A 100 base pair marker (Pharmacia, LKB) was included on every gel. 


\section{RESULTS AND DISCUSSION}

DNA extraction from soil has three requirements: extraction of high molecular weight DNA; extraction of DNA free from inhibitors for subsequent molecular biological manipulations to be performed; and representative lysis of microorganisms within the sample. In this paper, we tested a number of DNA extraction methods for their ability to fulfil these requirements.

DNA extracted using sonication was more degraded than for the other methods tested. The size of DNA extracted ranged from less than $500 \mathrm{bp}$ to greater than $20 \mathrm{~kb}$ in size. Methods that shear DNA, such as sonication, generally result in DNA of 100-500 bp (13). Higher molecular weight DNA is desirable for PCR since the greater the size of the DNA, the less likely is the formation of chimeras during PCR (15). The bead beating method used here performed better than those previously reported which usually extract DNA of less than $10 \mathrm{~kb}$ in size (3). The DNA extraction methods that did not use sonication all produced DNA of greater than $20 \mathrm{~kb}$.

Organic matter is the major source of inhibitors that may be co-extracted from soil with the microbial DNA. In particular, humic acids pose a considerable problem and will interfere in enzymatic manipulations of DNA $(5,14,16)$. DNA polymerases have been found to be inhibited by as little as $1 \mu 1$ of undiluted humic-acid-like extract, regardless of the amount of DNA present (16).

\begin{tabular}{|c|c|c|c|}
\hline Method* & Number of samples & $\mathrm{A}_{260 / 230}$ & $\mathrm{~A}_{260 / 280}$ \\
\hline Bacterial cells & 4 & $0.83 \pm 0.03$ & $1.10 \pm 0.003$ \\
\hline Chemical lysis & 10 & $1.06 \pm 0.03$ & $1.31 \pm 0.03$ \\
\hline Sonication & 4 & $1.20 \pm 0.10$ & $1.41 \pm 0.07$ \\
\hline Bead beating & 6 & $1.82 \pm 0.05$ & $1.69 \pm 0.02$ \\
\hline
\end{tabular}

* DNA diluted $1: 100$

The humic materials in soil have similar size and charge characteristics to DNA resulting in their copurification (17), evident by the extractions being brown in colour. Humic contaminants also interfere in DNA quantitation since they exhibit absorbance at both $230 \mathrm{~nm}$ and at $260 \mathrm{~nm}$, the later used to quantitate DNA. This characteristic can be used to determine the level of contamination of humic material by examining absorbance ratios. A high 260/230 ratio (>2) is indicative of pure DNA, while a low ratio is indicative of humic acid contamination and a high 260/280 ratio (>1.7) is indicative of pure DNA, while a low ratio is indicative of protein contamination. When the DNA extraction methods were compared (Table 2), the bead beating method consistently extracted DNA with higher 260/230 and 260/280 ratios. This indicated that the DNA was contaminated with fewer humic acid-like compounds. Although the extracts were still brown in colour, dilution of the DNA to 1:50 from all methods was suitable to produce a PCR product. Heavy metal ions, such as are present in the Balmain soil (Table 1), also contribute to inhibitory effects (18). Here we have demonstrated that a PCR product from soil DNA contaminated with humic acids and heavy metals can be obtained without the use of expensive purification products. 


\begin{tabular}{lccc}
\hline \multicolumn{4}{l}{ Table 3: Crude DNA ratios for different soil samples extracted using bead beating. } \\
\hline Sample $*$ & Soil type & A 260/230 & A 260/280 \\
\hline Western Sydney & Clay loam & 1.22 & 1.42 \\
Macquarie University & Clay loam & 1.83 & 1.71 \\
Ku-Ring-Gai Chase & Loamy sand & 1.03 & 1.30 \\
Balmain Power Station & Loamy sand & 1.33 & 1.53 \\
\hline
\end{tabular}

* DNA diluted $1: 100$

To determine the diversity of microorganisms from which DNA had been extracted, different primer sets were tested (Table 4), including both multi- and single-copy genes. The multi-copy targets included the prokaryotic small subunit rRNA (19), prokaryotic rRNA intergenic spacer region (20), the eukaryotic rRNA internal transcribed spacer (ITS) region (21), the ITS region for lichen fungi (22), and the HSP70 family of proteins (23) while the low abundance targets included fungal $\beta$-tubulin (24), and nifH genes (25). With dilution of DNA from each extraction technique, successful PCR amplification was achieved with all primers tested (see Fig. 1). The only exception to this was for the DNA extracted after differential centrifugation to separate the bacterial cells. An amplification product was not found when the eukaryotic specific primers for fungal ITS were used. Due to the centrifugation step in this method, fungal cells will be underrepresented. The PCR results provide good evidence for representative lysis of organisms with all other extraction methods.

\begin{tabular}{|c|c|c|}
\hline Target for amplification & Primer sequence & Reference \\
\hline Prokaryotic 16S rRNA & $\begin{array}{l}\text { FORB 5' AGAGTTTGATCCTGGCTCAG, REVB 5' } \\
\text { GGTTACCTTGTTACGACTT }\end{array}$ & 19 \\
\hline $\begin{array}{l}\text { Prokaryotic rRNA intergenic spacer } \\
\text { (IGS) region }\end{array}$ & $\begin{array}{l}\text { SPRRNAF 5' GAAGTCGTAACAAGG SPRRNAR 5' } \\
\text { CAAGGCATCCACCGT }\end{array}$ & 20 \\
\hline $\begin{array}{l}\text { Eukaryotic rRNA internal transcribed } \\
\text { spacer (ITS) region }\end{array}$ & $\begin{array}{l}\text { ITS1 5' TCCGTAGGTGAACCTGCGG ITS4 5' } \\
\text { TCCTCCGCTTATTGATATGC }\end{array}$ & 21 \\
\hline Fungal specific ITS & $\begin{array}{l}\text { LICHITSF 5' GCGGAAGGATCATTACTGAG } \\
\text { LICHITSR 5' GGGTATCCCTACCTGATCCG }\end{array}$ & 22 \\
\hline HSP70 & $\begin{array}{l}\text { HSP1 5' CA(AG)GC(I)AC(I)AA(AG)GA(CT)GC(I)GG } \\
\text { HSP2 5, GC(I)AC(I)GC(CT)TC(AG)TC(I)GG(AG)TT }\end{array}$ & 23 \\
\hline Fungal $\beta$-tubulin & $\begin{array}{l}\text { GEN C 5' GAGGAATTCCCAGACCGTATGATG } \\
\text { GEN D 5' GCTGGATCCTATTCTTTGGGTCGAACAT }\end{array}$ & 24 \\
\hline nifH gene & $\begin{array}{l}\text { NIFH1 5' } \\
\text { CTG(CT)GA(CT)CC(ACGT)AA(AG)GC(ACGT)GA } \\
\text { NIFH2 5, } \\
\text { G(AGT)(ACGT)GCCATCAT(CT)TC(ACGT)CC }\end{array}$ & 25 \\
\hline
\end{tabular}

Of the DNA extraction methods tested, sonication did not produce high molecular weight DNA while the differential centrifugation method generated a DNA pool dominated by bacterial DNA and therefore not suitable for analysis of eukaryotes. Neither of these methods fulfilled all requirements for a suitable DNA extraction method. The enzymatic lysis method relies on proteinase $\mathrm{K}$ digestion of microbial cells 
to release DNA while bead beating relies on ballistic disintegration of all cells. Therefore, bead beating is more likely to result in effective lysis of all soil organisms. Due to ease of the method, the reduced coextraction of inhibitors (Tables 2 and 3) and the greater confidence that bead beating would lyse all microbial cells in the soil, this was the method of choice and concentrated on for further analysis (see 1). Bead beating has been found to have a lysis efficiency of greater than $90 \%$ (3). The PCR results reported here provide further evidence to support this with products from both bacterial and fungal elements of the soil microbiota being obtained. The bead beating direct lysis method described here extracts between 1.5 and $2.35 \mathrm{mg} / \mathrm{ml}$ of DNA from $100 \mathrm{~g}$ of soil or $15-23.5 \mu \mathrm{g}$ DNA/g soil. Extraction methods using small soil samples ranging from $5 \mathrm{~g}$ to $100 \mathrm{mg}$ of soil have extracted $9-25 \mu \mathrm{g}$ DNA/g soil (6), $12 \mu \mathrm{g} / \mathrm{g}$ (18), 1$100 \mu \mathrm{g} / \mathrm{g}$ (26), and 2.5-26.9 $\mu \mathrm{g} / \mathrm{g}$ (11). The method described here is therefore at least as efficient as the above methods.

The focus of DNA extraction methods has moved to rapid performance of molecular techniques, avoiding extensive purification steps $(7,27)$. Using the bead beating DNA extraction method described here, crude microbial DNA could be extracted

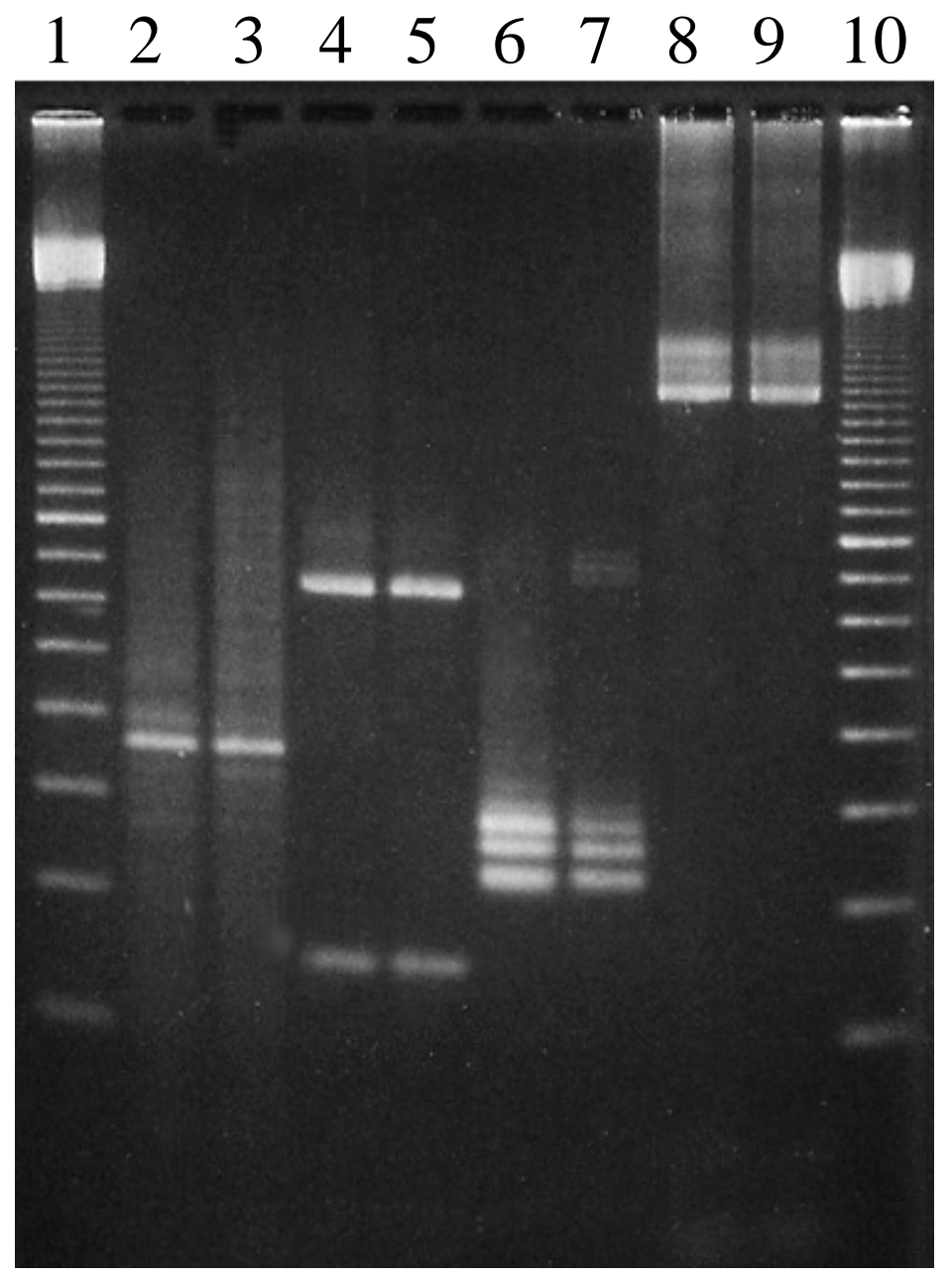

Figure 1 : Example of PCR amplification products using various DNA targets with soil extracted by enzymatic lysis or bead beating. Lane 1: 100 bp marker; lane 2: enzymatic lysis DNA with 16S rRNA primers (19); lane 3: bead beating DNA with 16S rRNA primers (19); lane 3: enzymatic lysis DNA with fungal ITS primers (22); lane 4: bead beating DNA with fungal ITS primers (22); lane 5: enzymatic lysis DNA with $h s p 70$ primers (23); lane 6: bead beating DNA with $h s p 70$ primers (23); lane 7: enzymatic lysis DNA with nifH primers (25); lane 8: bead beating DNA with nifH primers (25); lane 9: 100 bp marker. from a variety of soil types and dilution of this DNA was sufficient for successful PCR from both highand low-copy number genes. The described method allows the use of large scale preparations providing greater probability of detecting genes present in low abundance in the soil environment. Because this method is applicable to even the more challenging heavily contaminated soils, molecular microbial biodiversity assessment can now be more readily applied. 


\section{ACKNOWLEDGMENTS}

Thanks are due to Mr. Bruce Dowling of Pacific Power, Sydney for supplying soil from Balmain Power Station and to Dr. Geoff Humphreys, School of Earth Sciences, Macquarie University for identifying soil types. This is publication number 259 of the Key Centre for Biodiversity and Bioresources.

\section{REFERENCES}

1. Yeates, C., Gillings, M. R., Davison, A. D., Altavilla, N. and Veal, D. A. 1997. PCR amplification of crude microbial DNA extracted from soil. Letters in Applied Microbiology 25, 303-307.

2. Atlas, R. M. 1984. Diversity of microbial communities. Advances in Microbial Ecology 7, 1-47.

3. Ogram, A., Sayler, G. S. and Barkay, T. 1987. The extraction and purification of microbial DNA from sediments. Journal of Microbiological Methods 7, 57-66.

4. Steffan, R. J., Goksoyr, J., Bej, A. K. and Atlas, R. M. 1988. Recovery of DNA from soils and sediments. Applied and Environmental Microbiology 54, 2908-2915.

5. Holben, W. E., Jansson, J. K., Chelm, B. K. and Tiedje, J. M. 1988. DNA probe method for the detection of specific microorganisms in the soil bacterial community. Applied and Environmental Microbiology 54, 703-711.

6. Porteous, L. A. and Armstrong, J. L. 1991. Recovery of bulk DNA from soil by a rapid, small-scale extraction method. Current Microbiology 22, 345-348.

7. Borneman, J., Skroch, P. W., O'Sullivan, K. M., Palus, J. A., Rumjanek, N. G., Jansen, J. L., Nienhuis, J. and Triplett, E. W. 1996. Molecular microbial diversity of an agricultural soil in Wisconsin. Applied and Environmental Microbiology 62, 1935-1943.

8. More, M. I., Herrick, J. B., Silva, M. C., Ghiorse, W. C. and Madsen, E. L. 1994. Quantitative cell lysis of indigenous microorganisms and rapid extraction of microbial DNA from sediment. Applied and Environmental Microbiology 60, 1572-1580.

9. Tebbe, C. C. and Vahjen, W. 1993. Interference of humic acids and DNA extracted directly from soil in detection and transformation of recombinant DNA from bacteria and a yeast. Applied and Environmental Microbiology 59, 2657-2665.

10. Tsai, Y.-L. and Olson, B. H. 1991. Rapid method for direct extraction of DNA from soil and sediments. Applied and Environmental Microbiology 57, 1070-1074.

11. Zhou, J., Bruns, M. A. and Tiedje, J. M. 1996. DNA recovery from soils of diverse composition. Applied and Environmental Microbiology 62, 316-322.

12. Sambrook, J., Fritsch, E. F. and Maniatis, T. . 1987. Molecular cloning - a laboratory manual. Cold Spring Harbor, USA, Cold Spring Harbor Laboratory Press.

13. Picard, C., Ponsonnet, C., Paget, E., Nesme, X. and Simonet, P. 1992. Detection and enumeration of bacteria in soil by direct DNA extraction and polymerase chain reaction. Applied and Environmental Microbiology 58, 2717-2722.

14. Steffan, R. J. and Atlas, R. M. 1988. DNA amplification to enhance detection of genetically engineered bacteria in environmental samples. Applied and Environmental Microbiology 54, 21852191. 
15. Liesack, W., Weyland, H. and Stackebrandt, E. 1991. Potential risks of gene amplification by PCR as determined by $16 \mathrm{~S}$ rDNA analysis of a mixed-culture of strict barophilic bacteria. Microbial Ecology 21, 191-198.

16. Tsai, Y.-L. and Olson, B. H. 1992. Detection of low numbers of bacterial numbers in soils and sediments by polymerase chain reaction. Applied and Environmental Microbiology 58, 754-757.

17. Holben, W. E. 1994. Isolation and purification of bacterial DNA from soil. Methods of Soil Analysis, Part 2. Microbiological and Biochemical Properties. Madison, USA, Soil Science Society of America: 727-751.

18. Tsai, Y.-L. and Olson, B. H. 1992. Rapid method for separation of bacterial DNA from humic substances in sediments for polymerase chain reaction. Applied and Environmental Microbiology 58, 2292-2295.

19. Edwards, U., Rogall, T., Blocker, H., Emde, M. and Bottger, E. C. 1989. Isolation and direct complete nucleotide determination of entire genes: characterization of a gene coding for $16 \mathrm{~S}$ ribosomal RNA. Nucleic Acids Research 17, 7843-7853.

20. Jensen, M. A., Webster, J. A. and Straus, N. 1993. Rapid identification of bacteria on the basis of polymerase chain reaction-amplified ribosomal DNA spacer polymorphisms. Applied and Environmental Microbiology 59, 945-952.

21. White, T. J., Bruns, T., Lee, S. and Taylor, J. 1990. Amplification and direct sequencing of ribosomal RNA genes for phylogenetics. PCR protocols : a guide to methods and applications. M. A. Innis, D. H. Gelfand, J. J. Sninsky and T. J. White, Academic Press: 315-322.

22. Gillings, M. R. 1998. Personal communication.

23. Yap, W. H., Li, X., Soong, T. W. and Davies, J. E. 1996. Genetic diversity of soil microorganisms assessed by analysis of $h s p 70$ (dnaK) sequences. Journal of Industrial Microbiology 17, 179-184.

24. Koenraadt, H., Somerville, S. C. and Jones, A. L. 1992. Characterisation of mutations in the betatubulin gene of benomyl resistant field strains of Venturia inaequalis and other pathogenic fungi. Phytopathology 82, 1348-1354.

25. Zehr, J. P. and McReynolds, L. A. 1989. Use of degenerate oligonucleotides for amplification of the nifH gene from the marine cyanobacterium Trichodesmium thiebautii. Applied and Environmental Microbiology 55, 2522-2526.

26. Porteous, L. A., Armstrong, J. L., Seidler, R. J. and Watrud, L. S. 1994. An effective method to extract DNA from environmental samples for polymerase chain reaction amplification and DNA fingerprint analysis. Current Microbiology 29, 301-307.

27. Volossiouk, T., Robb, E. J. and Nazar, R. N. 1995. Direct DNA extraction for PCR-mediated assays of soil organisms. Applied and Environmental Microbiology 61, 3972-3976. 